\title{
Atferdskontrollerende trening ved tics
}

\section{Vedlikehold av et levende norsk medisinsk fagspråk krever et bevisst forhold til oversettelse og bruk av nye fremmedspråklige faguttrykk.}

Terapiformen «habit reversal training» (HRT), som på norsk er oversatt med ticskontrollerende trening, er en kognitiv atferdsterapi som brukes for å behandle flere ulike former for repetitive atferdsforstyrrelser. Metoden går ut på å øke pasientens oppmerksomhet på den repeterende atferden, for deretter å forsøke å utvikle en alternativ respons på trangen til å utføre den. En amerikansk studie viser at denne terapiformen kan gi signifikant mindre tics hos barn med Tourettes syndrom (1). Behandlingsmetoden blir imidlertid mer og mer erstattet av den noe mer omfattende «comprehensive behavioral intervention for tics» (CBIT). Dermed er det behov for et norsk uttrykk også for dette begrepet.

Terapiformen fjerner ikke egentlig den uønskede atferden, men kan være en hjelp til å kontrollere den. En norsk oversettelse bør vise dette, og også at terapiformen har et sentralt element av trening. Oversettelsen bør være kortfattet nok til å kunne inngå i dagligtalen der slik terapiform benyttes, i tillegg til å være gjenkjennelig med henblikk på originalbetegnelsen og gjenspeile det atferdsterapeutiske elementet i terapiformen. Vi foreslår derfor å benytte atferdskontrollerende trening ved tics som norsk betegnelse.

\section{Are Brean}

are.brean@legeforeningen.no

Tidsskriftet

\section{Kerstin J. von Plessen}

Regionsenter for barn og unges psykiske helse Bergen

\section{Ebba Wannag}

Nasjonalt kompetansesenter for AD/HD,

Tourettes syndrom og narkolepsi

Oslo universitetssykehus

\section{Litteratur}

1. Brean A. Atferdsterapi er effektivt ved Tourettes syndrom. Tidsskr Nor Legeforen 2010; 130 : 2004

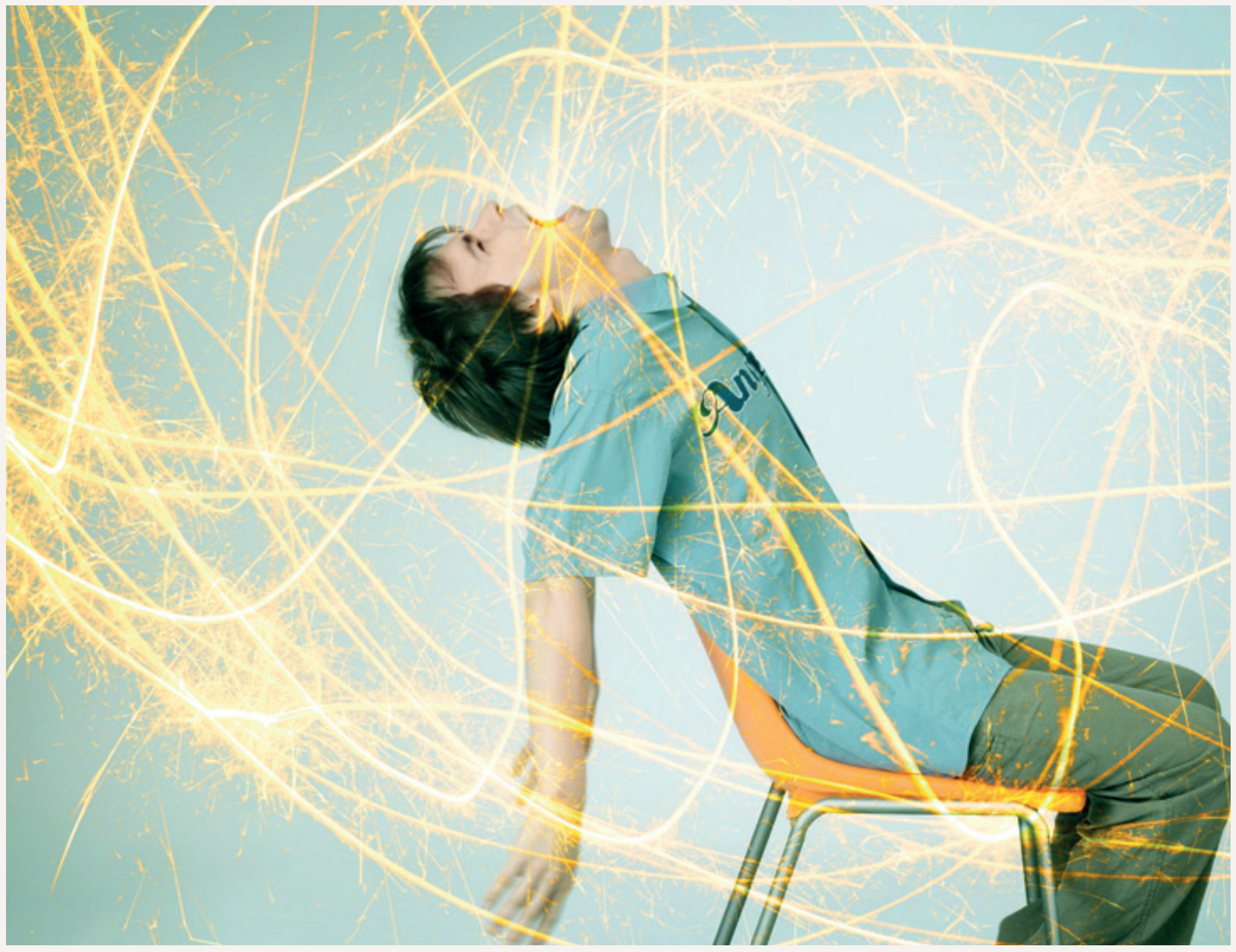

